\title{
The host-range, genomics and proteomics of Escherichia coli 0157:H7 bacteriophage rV5
}

Andrew M Kropinski ${ }^{1,2}$, Tom Waddell ${ }^{3}$, Juncai Meng ${ }^{4}$, Kristyn Franklin ${ }^{1}$, Hans-Wolfgang Ackermann ${ }^{5}$, Rafiq Ahmed ${ }^{6}$, Amanda Mazzocco ${ }^{1}$, John Yates $1 \mathrm{II}^{7}$, Erika J Lingohr ${ }^{1}$ and Roger P Johnson ${ }^{1 *}$

\begin{abstract}
Background: Bacteriophages (phages) have been used extensively as analytical tools to type bacterial cultures and recently for control of zoonotic foodborne pathogens in foods and in animal reservoirs.

Methods: We examined the host range, morphology, genome and proteome of the lytic E. coli O157 phage rV5, derived from phage V5, which is a member of an Escherichia coli O157:H7 phage typing set.

Results: Phage rV5 is a member of the Myoviridae family possessing an icosahedral head of $91 \mathrm{~nm}$ between opposite apices. The extended tail measures $121 \times 17 \mathrm{~nm}$ and has a sheath of $44 \times 20 \mathrm{~nm}$ and a $7 \mathrm{~nm}$-wide core in the contracted state. It possesses a 137,947 bp genome (43.6 mol\%GC) which encodes 233 ORFs and six tRNAs. Until recently this virus appeared to be phylogenetically isolated with almost $70 \%$ of its gene products ORFans. rV5 is closely related to coliphages Delta and $\mathrm{VB}-\mathrm{ECOM}-\mathrm{FY} 3$, and more distantly related to Salmonella phages PVP-SE1 and SSE-121, Cronobacter sakazakii phage VB_CsaM_GAP31, and coliphages phAPEC8 and phi92. A complete shotgun proteomic analysis was carried out on rV5, extending what had been gleaned from the genomic analyses. Host range studies revealed that rV5 is active against several other E. coli.
\end{abstract}

Keywords: E. coli O157:H7, Phage evolution, Phage ecology, Myoviridae, Genomics, Proteomics, Bioinformatics, Pyrosequencing, Tail spike

\section{Background}

Since Escherichia coli O157:H7 is associated with foodborne illness in humans with serious complications such as hemorrhagic colitis and the hemolytic uremic syndrome, much effort has been directed at understanding the epidemiology and virulence of this zoonotic bacterium [1,2], and minimizing its carriage by cattle through phage biocontrol [3-5].

The scientific literature lists over fifty phages described as being E.coli O157-specific. These include sixteen phages (V1-V16) comprising part of a phage typing scheme for this bacterium [6] plus phages 38, 39, 41, 42, ECB7 and ECA1 [7]; AR1 [8,9]; Bo-21, Av-05, Av-06, and Av-08 [10]; CA933P, CA911 MFA933P and MFA45D [11]; CEV1 and CEV2 [12,13]; CSLO157 [14]; DC22 [15], e4/1c and e11/2 [16]; ECML-4, ECML-117, and ECML-134 [17]; JK06; KH1, KH4 and KH5 [18]; LG1 [19]; $\varphi$ V10 [20,21]; PP01

\footnotetext{
* Correspondence: Roger.Johnson@phac-aspc.gc.ca

${ }^{1}$ Public Health Agency of Canada, Laboratory for Foodborne Diseases, 110 Stone Road West, Guelph, ON N1G 3W4, Canada

Full list of author information is available at the end of the article
}

[22]; SFP10 [23]; SH1 [24]; SP15, SP21, and SP22 [25]; vB_EcoM_CBA120 [5]; vB_EcoS_AKFV33 [4]; and, vB_EcoS_Rogue1 [26]. However, relatively little or consistent information on morphology and taxonomic position, host range, receptor specificity, genome size and characterization is available for many of these viruses.

Only a limited number of these viruses have been fully sequenced. They include members of the Myoviridae (AR1, V7, wV8, CBA120, SFP10), Siphoviridae (JK06; Rogue1; AKVF33) and Podoviridae ( $\varphi$ V10) viral families. All are lytic phages except the latter virus which is temperate. The myoviruses include representatives of three viral genera: the "FelixO1likevirus" (wV8; [27,28]), the "Viunalikeviruses" (CBA120 and SFP10; [29] and the "T4likeviruses" (AR1 and V7 [30]) and the "T5like viruses" (AKVF33). The siphoviruses belong to the "Tunalikevirus" genus (JK06, Rogue1) or "T5likevirus" (AKFV33), while the member of the Podoviridae is related to Group E1 Salmonella enterica-specific bacteriophage $\varepsilon 15$ [31], making it a member of the "Epsilon15likevirus" genus [28].

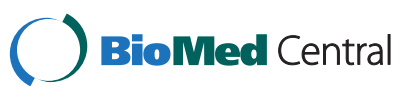


We describe here the host range, morphology, genome and proteome of a phage designated $\mathrm{rV} 5$, considered a derivative of the typing phage V5 of the original E. coli O157:H7 phage typing set [6]. Phage rV5 was the predominant phage recovered (hence "r"V5) from the feces of calves experimentally infected with $E$. coli O157: H7 and treated successfully with a cocktail of six of these typing phages including V5 during a phage therapy trial $[32,33]$. Although having the same host range as V5, as shown below, rV5 was considered distinct from V5 as rV5 may have acquired other attributes during passage through the calves that would enhance its value as a candidate therapeutic phage.

\section{Results}

\section{Host-range of phage rV5}

The phage was tested for lytic activity on reference strains of 12 common phage types of E. coli O157:H7 and the ECOR collection [34]. The host range and activity of $\mathrm{rV} 5$ on these 12 is the same as previously found for phage V5 (data not shown). Six (50\%) of the 12 O157:H7 phage type reference strains were susceptible; four being highly susceptible ( $>50 \%$ lysis) (Additional file 1 : Table S1). Seventeen (24\%) of 72 strains of the ECOR collection showed evidence of lysis, although only one strain was highly susceptible ( $>50 \%$ lysis) (Additional file 2 : Table S2) Among these 17 strains, five had $\mathrm{O}$ antigens shared by other diarrheagenic E. coli: O7, enteroaggregative E. coli; $\mathrm{O} 25$ and $\mathrm{O} 173$, enterotoxigenic E. coli; O113, enterohemorrhagic E. coli; and O167, enteroinvasive E. coli [35].

\section{Morphology of rV5}

Phage rV5 has a contractile tail and is therefore a member of the Myoviridae family. This virus has an icosahedral head with a diameter of $91 \mathrm{~nm}$ between opposite apices. The extended tail measures $121 \times 17 \mathrm{~nm}$ and has a sheath of $44 \times 20 \mathrm{~nm}$ and a $7 \mathrm{~nm}$-wide core in the contracted state. Five to six thin tail fibers of $70 \mathrm{~nm}$ in length are occasionally seen (data not shown).

\section{Properties of the phage genome}

The sequence of the rV5 phage genome was determined through sequencing of two random clone libraries and by primer walking using the phage DNA as a template. All 846 sequence reactions at approximately 600 bp per reaction resulted in 3.6 fold coverage of the genome. The final sequence of the circularly permuted genome $(137,947 \mathrm{bp}, 43.6 \mathrm{~mol} \%$ GC) is very similar to the size estimated by PFGE $(132.5 \mathrm{~kb}$; Figure 1). An analysis of the variation in base composition over the entire length of the genome

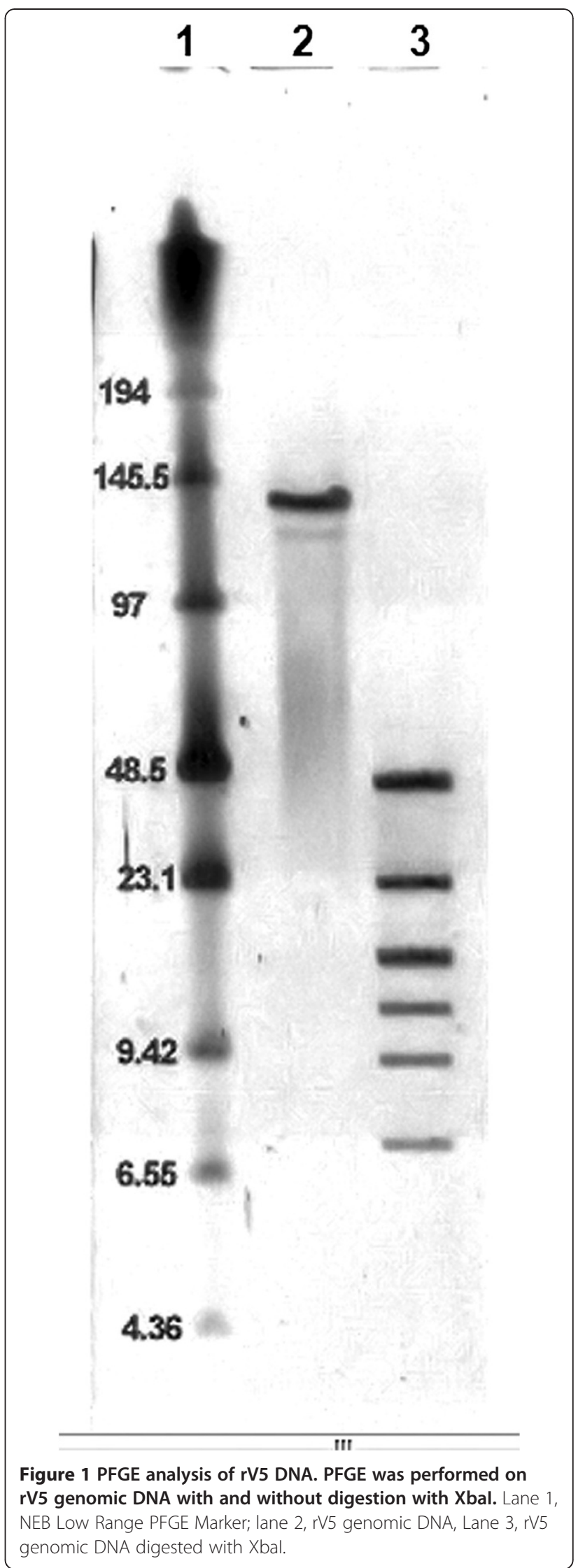


revealed very little evidence of horizontally acquired genes [36].

\section{tRNAs}

Like many of the larger members of the Myoviridae, rV5 codes for tRNAs. Five $\left(\operatorname{Arg}_{\mathrm{AGA}}, \mathrm{Tyr}_{\mathrm{TAC}}, \mathrm{Thr}_{\mathrm{ACA}}\right.$, Met $_{\mathrm{ATG}}$, Pro $_{\mathrm{CCA}}$ ) were identified using the tRNAScan program [37] and an additional one ( $\left.\operatorname{Ser}_{\mathrm{TGA}}\right)$ was detected using ARAGORN [38]. In E. coli O157:H7 strains AGA is used as the Arg codon $5.1 \%$ of the time, followed by threonyl codon ACA (14.6\%), prolyl codon CCA (19.1\%), tyrosyl codon TAC (42.7\%), and methionyl codon ATG (100\%). By comparison, rV5 uses these same codons $26,35,29,46$ and $100 \%$ of the time. It would appear that the presence of the $\mathrm{RNAA}_{\mathrm{Arg}}$ and the tRNA $_{\text {Pro }}$ homologs would increase the rate of translation of phage mRNAs. Methionyl tRNA, while seemingly unwarranted, occurs in many members of the Myoviridae including Aeromonas phage Aeh1 (2 copies, NC_005260), mycobacteriophages Bxz1 (2 copies, NC_004687), vibriophage KVP40 (NC_005083), Listeria phage P100 (NC_007610), and Synechococcus phage S-PM2 (3 copies, NC_006820). This suggests that the presence of additional $\mathrm{tRNA}_{\mathrm{Met}}$ may facilitate the rapid translation of phage mRNAs.

\section{Identification of ORFs}

The ORFs for rV5 were identified using the Kodon software package from Applied Maths (Austin, TX). In almost every case upstream there was a sequence showing considerable similarity to the consensus ribosomebinding site ( $5^{\prime}$ GGAGGT3'). A total of 233 ORFs were discovered most closely packed or overlapping. The total codon capacity of the genome was 91.6\% (average $0.54 \mathrm{~kb}$ per ORF) (Figure 2). The rV5 genome contained 88 mainly small ORFs between 92269-121323 and no observable ORFs from regions 104013-106618. Prior to our description of Salmonella phage PVP-SE1 [39], only 73 (31\%) of gene products of rV5 possessed homologs to proteins in the nonredundant databases; and, only 44 (19\%) were homologous to phage proteins. The rV5 proteome was scanned with TMHMM [40], and Phobius [41] programs, revealing that 15 proteins possessed transmembrane domains (Additional file 3: Table S3).

\section{Transcription}

From the gene layout in Figure 2, we propose that rV5 contains four transcriptional units comprising genes 10-1-238-164, 11-26, 27-81, and 82-163, respectively. Based upon the gene arrangement, we would minimally expect bidirectional transcriptional terminators between genes 26 and 27 and genes 163 and 164 , and bidirectional promoters between genes 10 and 11 and 81 and 82, respectively. Of these sites, only the bidirectional terminators were located between genes 26 and 27. In addition, bidirectional promoters were discovered between genes 10 and 11. In total, using stringent selection processes, 33 promoters and 20 rho-independent terminators where discovered in the rV5 genome (Additional file 4: Table S4). All had extensive homology to the consensus E. coli promoters, with 11 possessing extended -10 regions [34,35]. Since these promoters are distributed across the rV5 genome, it suggests that modification of the host holo-RNA polymerase, as observed with coliphage T4 to permit recognition of different promoter classes [42], might not occur in rV5. To investigate this further, we selected the upstream sequence for late genes (27-66) and resubmitted it to MEME [43]. Eight copies of a motif (TggTAaAAtA) which is similar to the T4 late promoter consensus sequence (TATAAATA) [44,45], were identified (Additional file 4: Table S4). Late transcription in T4-like phages is dependent upon three gene products, namely gp45 (RNA polymerase recruitment), gp33 (co-activator of late transcription) and gp55 (late promoter recognition protein). There are no homologs for these proteins in rV5.

PSI-BLAST analysis of gp11 revealed that it is probably a Srd homolog. These proteins are postulated to act as antisigma factors functioning as decoys for RpoD and RpoS. It is homologous to similar proteins in coliphages $\mathrm{T} 4$ (NP_049634), Acinetobacter phage 133 (YP_004300600) and Pseudomonas phage $\varphi$ Pto-bp6g (AEO14611). Perhaps this is used as a part of a molecular switch between early and late transcription.

\section{Nucleotide metabolism and DNA replication}

Phage rV5 contains numerous genes involved in nucleotide metabolism and DNA replication. Among the former we found genes coding for exo- (gp94) and endodeoxyribonucleases (gp213), the anaerobic and aerobic ribonucleotide reductase subunits (gp109-112 and 117), and thymidylate synthase (gp106). This group of enzymes is also commonly found in many other members of the Myoviridae and is collectively responsible for generating deoxyribonucleotides for phage DNA synthesis. The ribonucleoside-diphosphate reductases are responsible for the interconversion of ribo- to deoxyribonucleotides and are usually represented by three main classes: class I complex of NrdAB or NrdEF which requires oxygen for activity; class II containing NrdJ and the oxygen-sensitive; class III encoded by NrdDG [46]. As with coliphages RB43, RB49 and RB69, phage rV5 contains homologs of the hosts NrdAB and NrdDG proteins.

Among the enzymes directly involved in DNA replication are a DNA ligase (gp88), DNA polymerase (gp228), and two possible helicases (gp230, gp237). gp88 contains 

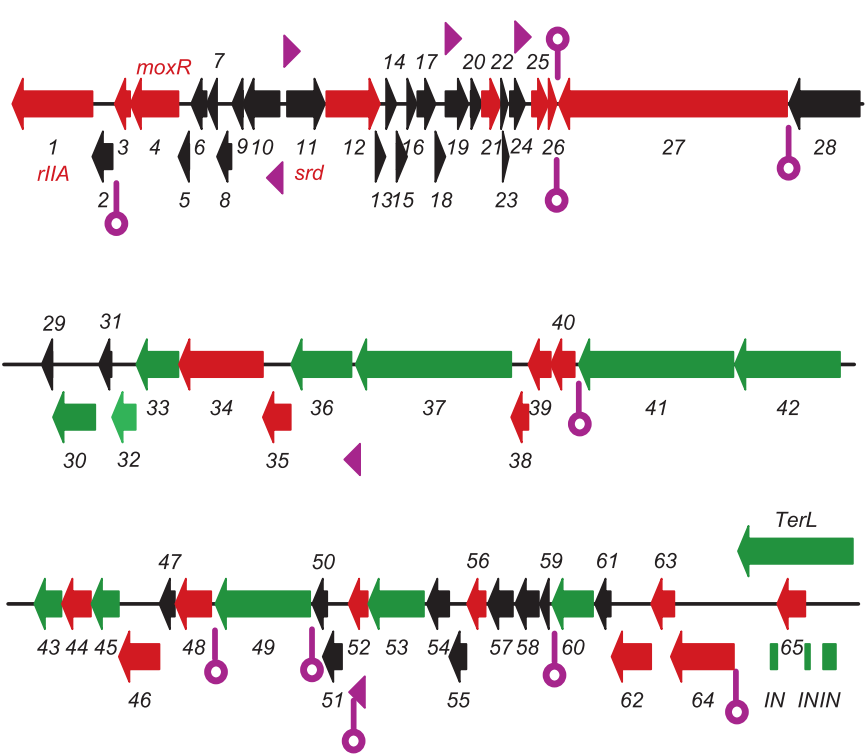

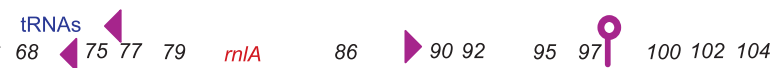
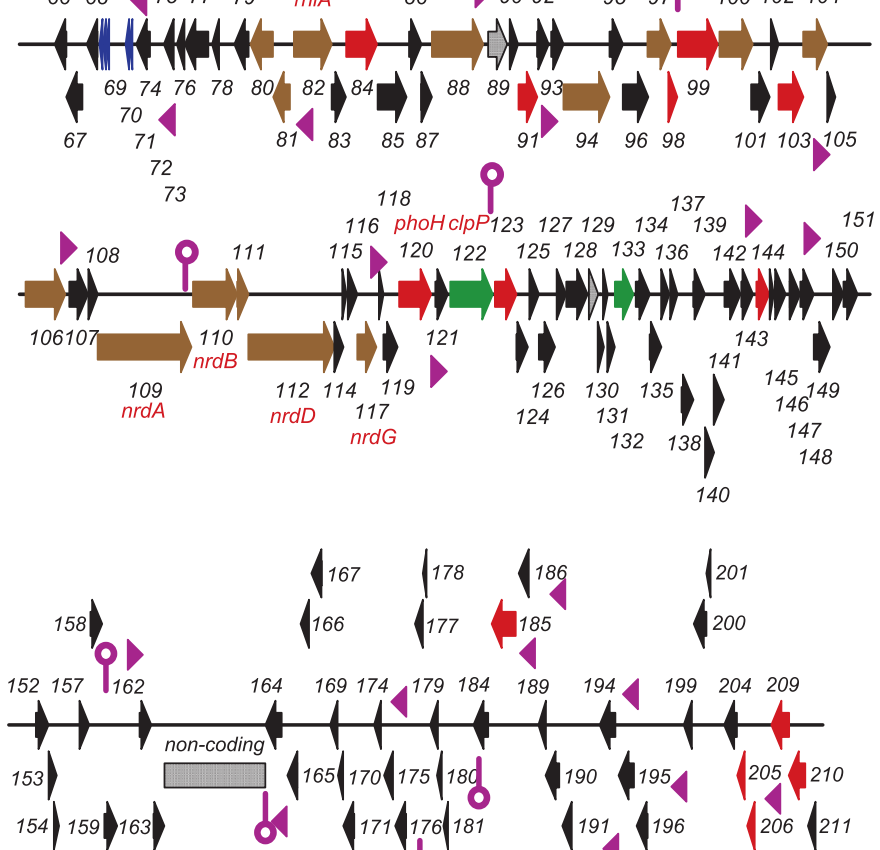

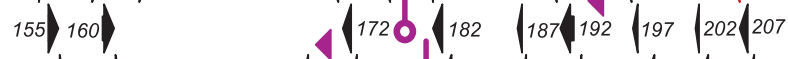

156) $\left.{ }_{161}\right) \quad \mid \begin{aligned} & 168 \\ & \mid 73\end{aligned}$

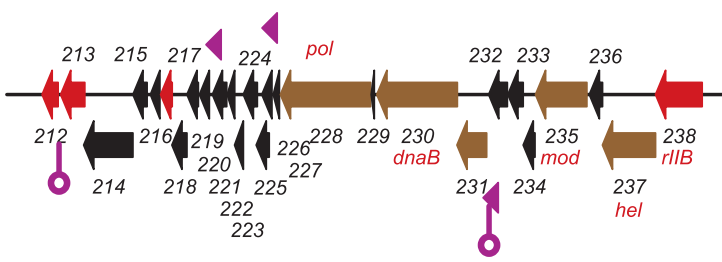

Figure 2 (See legend on next page.) 
a PRK09125 DNA ligase domain and its closest homolog in ATP-dependent DNA ligase of Enterobacteria phage vB_EcoM-FV3 (AEZ65217), Salmonella phage 7-11 (YP_004782418) [47] and Pseudomonas phage P3_CHA (ADX32167) [48]. The 775 amino acid rV5 DNA polymerase (gp228), possesses a smart00482 (POLAc) DNA polymerase A and, a DNA_pol_A_pol_I_B (cd08643) domain. Its closest homologs are in Enterobacteria phage vB_EcoM-FV3 (AEZ65345), Cronobacter phage CR3 (AFH21225) [49] and Vibrio phage ICP1_2001_A (ADX89239) - all members of the Myoviridae. Gp230 contains C-terminal GP4d_helicase (cd01122) and DnaB (COG0305) domains. Again its homologs are to proteins in vB_EcoM-FV3 (AEZ65346), CR3 (AFH21242) as well as to primase/helicases in members of the Podoviridae. The product of gene 237 has PIF1 (pfam05970), PIF1like helicase and RecD (COG0507), ATP-dependent exoDNAse (exonuclease $\mathrm{V}$ ), alpha subunit domains, and again shows homology to proteins in phages vB_EcoMFV3 and CR3.

In an effort to define the origin of replication of this phage, Grigoriev AT- and GC-skew analysis was undertaken [50-53]. The rV5 genome revealed changes at nucleotides $6425, \quad 13675-13725,66675-66725$ and 104425-105475, all of which appear to be associated with a change in the orientation of transcription.

\section{Proteomics and morphogenesis}

The proteomics of rV5 were investigated in three ways. (1) The proteins were screened for homologs to structural proteins in other phages using the BLASTP program, (2) the virions were studied by one-dimensional SDS-PAGE (data not shown) and (3) the total phage proteome was investigated by mass spectrometry (Additional file 5: Table S5). SDS-PAGE revealed at least 10 bands, the five major ones having relative molecular weights of 288.2, 174.0, 52.3, 26.1 and $9.7 \mathrm{kDa}$. Among the proteins detected by total phage proteomics were the putative tail proteins (gp37, 42 and 49), tail fibre proteins (gp30, 32, 33, 41 and 43), tail baseplate (gp36 and 45), and a major capsid protein (gp60).

The five proteins that deserve further attention are gp30, 33, 37, 41 and 43 since they appear to specify tail fiber-like proteins which play crucial roles in phage adsorption to its host. These proteins were analyzed using HHpred [54]. Gp30, a 347 amino acid protein, contained a domain with significant similarity (Probab $=98.39 \mathrm{E}$-value $=9 \mathrm{e}-08$ ) to the short tail fibers of coliphage T4 (Gp12) which are involved in LPS-binding (PDB accession number 1PDI; [55]). Interestingly, the similarly sized Gp33 also shows significant homology (Probab=97.69 E-value=7.5e-06) to this same protein. These two proteins show $42.3 \%$ sequence identity using the ALIGN Query program [56] which suggests that two chemotypes of LPS may be recognized.

With 1279 amino acid residues, gp37 is one of the largest proteins specified by this virus. Its domains include COG4733 [phage-related protein, tail component]. The phage homologs include Shewanella prophage MUSO2, $43 \mathrm{kDa}$ tail protein 3CDD (Probab=97.13 E-value=0.011) and a Neisseria $43 \mathrm{kDa}$ prophage tail protein (Probab=97.05 $\mathrm{E}$-value $=0.0095)$. Gp41, a 1272 AA protein, possesses a C-terminal domain (3GW6, Probab $=98.69$ E-value $=1.5 e-$ $08)$ to an endo- $\mathrm{N}$-acetylneuraminidase from Enterobacteria phage K1F, a podovirus. This region shows a high probability of a coiled-coil structure as demonstrated using PCOILS [57,58]. The N-terminus of gp43 (222 AA) shows structural similarity to the $\mathrm{N}$-terminus of phage P22 tailspike protein (2VNL; Probab=96.34 E-value=0.00042).

Using Using mass spectrometry of trypsin-digested virions the following proteins were identified: gp52 (tail tube protein; $16.1 \%$ coverage), gp53 (tail sheath protein; $31.9 \%$ ), gp60 (major capsid protein; 83.3\%), gp61 (head decoration protein; $85.3 \%$ ), gp64 (portal protein; $36.3 \%$ ) all of which are expected to be major components of the viral particles. In addition, gp133 (15.9\%) was one of the predominant proteins (Additional file 5: Table S5). A comparison of phage rV5 and phi92 [59] permitted us to definitively identify the tail tube and sheath proteins.

\section{Introns in terminase}

BLASTX analysis revealed that the gene specifying the large subunit of the terminase complex was divided into three segments, one of which contained a homing endonuclease. While introns are not uncommon in myoviral genomes, being present in coliphage T4 [42], Aeromonas phage 25 (NC_008208), Pseudomonas phage $\varphi \mathrm{EL}$, and Synechococcus phage S-PM2, in only one other virus, siphovirus LL-H of Lactobacillus delbrueckii subsp. Lactis, does the TerL gene contain an intron [60].

\section{Lysis}

Lysis of infected bacteria is brought about through the sequential effects of a pore-producing protein - the holin and a peptidoglycan-degrading enzyme - the lysin. Holins usually contain 2-3 membrane spanning helices (TMD), a 
charged C-terminus and exhibit poor sequence identity to other functionally related proteins [61-63]. In many phages, a lysis cassette exists in the genome with the holin gene preceding that of the lysin. In rV5, Gp89 codes for an obvious lysin (pfam00959, Phage_lysozyme \& COG467, Muramidase) possessing strong sequence identity to the lysozymes of enterobacterial phages phage vB_EcoM-FV3, and Salmonella phage Vi II variant E1 [64]. Since no homolog to a holin was discovered, the rV5 proteome was scanned with TMHMM [40] and Phobius [41]. In only one case, gp129, did the two programs indicate that the protein contained two TMDs. This 78 amino-acid residue protein also possessed a high concentration of lysyland arginyl-residues in its $\mathrm{C}$-terminus suggesting that this putative holin is separated from to the lysin gene as in phage T4.

\section{Discussion}

\section{Host range studies}

Phage rV5 was subject to extensive host range studies, revealing virulence for numerous $E$. coli other than serotype O157:H7. The six E. coli O157:H7 phage type reference strains susceptible to rV5 together represent $73 \%$ of all isolates of E. coli O157:H7 phage typed at the National Microbiology Laboratory in Canada in 2007-2010 [65] [The National Microbiology Laboratory (NML) and Centre for Food-borne Environmental and Zoonotic Infectious Diseases (CFEZID) PHAC, Provincial Public Health Microbiology Laboratories. 2010 Annual Summary of Laboratory Surveillance Data. Forthcoming]. Also, among the susceptible E. coli strains of the ECOR collection were several that share the same $O$ antigens as other diarrheagenic $E$. coli. Since $O$ antigens are recognized as attachment sites for phages of Gramnegative bacteria, rV5 potentially may be activity against diarrheagenic E. coli other than E. coli O157:H7. Virulence for such a broad range of pathogens potentially is of value for candidate therapeutic phages, as has been noted previously [66].

\section{Evolutionary considerations}

The phylogenic origin of specific phages is always complicated by recombinational exchanges that have presumably occurred during the speciation of the virus. When this study was initiated in 2004, phage rV5 was a genomic orphan since the majority (ca. 70\%) of its genes were ORFans $[67,68]$. Since then five other phages have been reported to be rV5-like: coliphages vB_EcoM-FV3 [69], phAPEC8 [70] and phi92 [59], Cronobacter sakazakii phage vB_CsaM_GAP31 [71] and Salmonella phage PVP-SE1 [39]. To this list we can also add Salmonella phage SSE-121 (JX181824); and, coliphage Delta Y that Andrey Letarov and Alla Golomidova (Winogradsky
Institute of Microbiology, RAS, Moscow, Russia), isolated from horse manure, and partially sequenced. This once again illustrates that very similar phages may be isolated from widely different locales [72-74].

Based upon the proposed assignment to a genus being the presence of $40 \%$ conserved proteins $[28,75]$, the five fully sequenced phages could be grouped in the "V5likevirus" genus. The submitting author is now of the opinion that the use of the $40 \%$ protein homologs as an indication of membership in the same genus is too inclusive, resulting in, at least for the phages with large proteomes, "taxonomic lumping." At the protein level, rV5 and FV3 share $90.6 \%$ homologous proteins; while rV5 and PVP-SE1, only share $42.9 \%$ of the proteomic content. At the DNA level, rV5 and coliphage vB_EcoM-FV3 share 87.3\% DNA sequence identity, while rV5 and Salmonella phage PVP-SE1 share $<50 \%$ sequence identity. Based upon BLASTN analysis the mycobacteriophages have been grouped and subgrouped (http://phagesdb.org/; [76]). Using the same approach, complemented by progressiveMauve analyses (Figure 3) [77] we visualize the existence of three related genera - the "V5likevirus" (rV5, FV3), the "Pvplikevirus" (PVP-SE1, GAP31 and SSE-121) and the Phi92likevirus (phi92 and phAPEC8). The results of the progressiveMauve alignment also indicate a serious problem with the genomics of phages with circularly permuted genomes, that the genomes are not collinear. This is most apparent with the "Pvplikevirus" all of which start in radically different positions, which require realignment before running EMBOSS stretcher. The separation of the rV5related phages into three groups is also indicated by a phylogenetic analysis of their capsid proteins and DNA polymerases which clearly indicate three clades (Figure 4).

\section{Materials and methods \\ Bacteriophages and hosts}

Phage V5 was obtained from Rafiq Ahmed (National Microbiology Laboratory, Winnipeg, MN, Canada) and is part of a collection of E.coli O157:H7 typing phages [6]. Phage rV5 was isolated during a successful "proof of concept" study of phage therapy for E. coli O157:H7 infection of cattle; it was the predominant phage in the feces of calves that eliminated E. coli O157:H7 following oral administration of a mixture of V5 and five other lytic O157 phages [32,33]. Determination of the host range of rV5 and V5 propagated and quantitated on E. coli O157:H7 strain R508 for 12 E. coli O157:H7 phage type reference strains revealed they shared the same host range, consistent with the designation of $\mathrm{rV} 5$ as a derivative of V5.

\section{Host range study}

The virulence of phage rV5 for reference strains of 12 common phage types of E. coli $\mathrm{O} 157: \mathrm{H} 7$ and 72 strains of the ECOR collection [34] was determined by spotting 


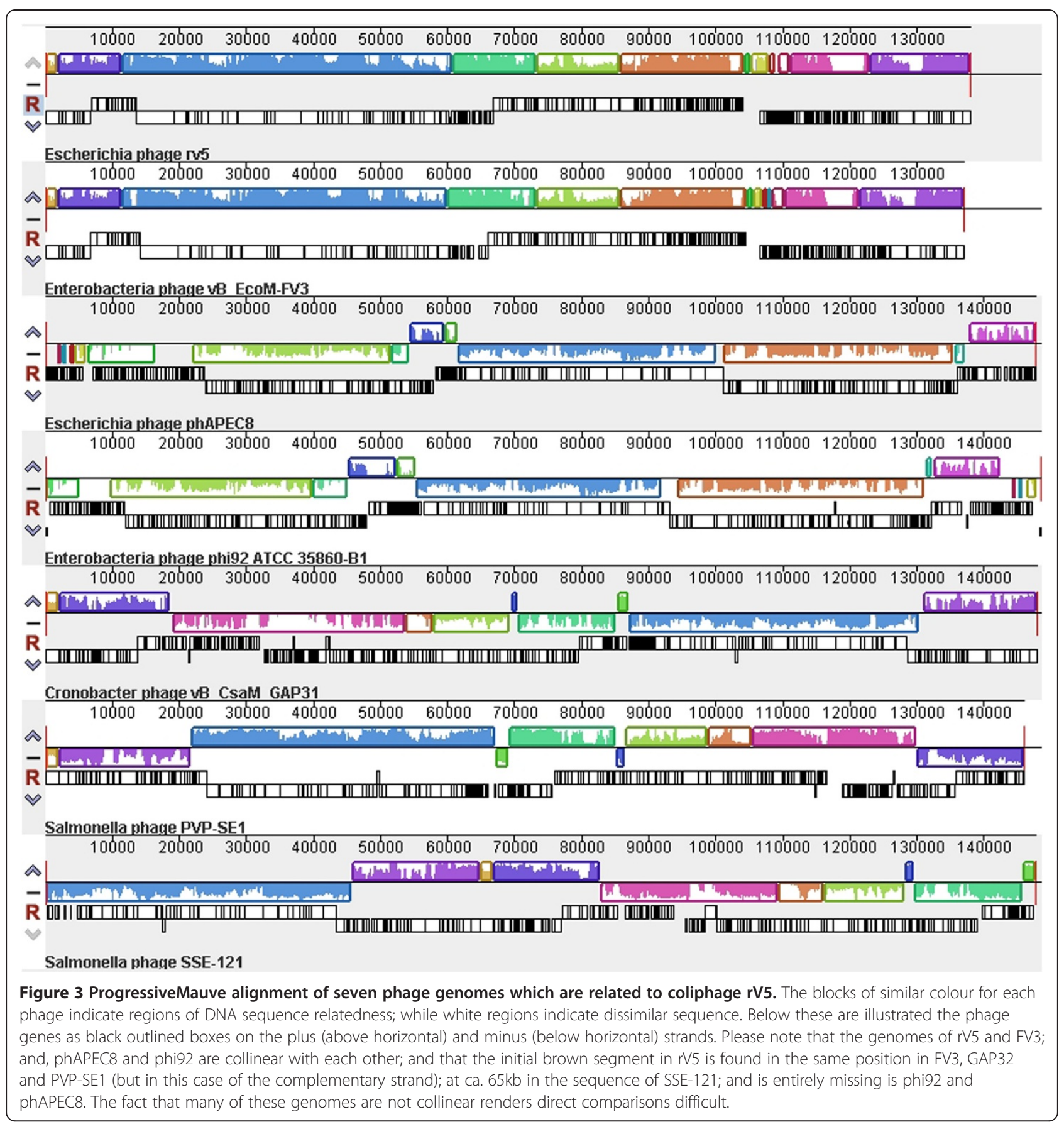

$10^{5}$ PFU of phage rV5 onto freshly seeded lawns of bacteria on agar plates [6].

\section{Electron microscopy}

Phage rV5 was sedimented for $60 \mathrm{~min}$ at 25,000 $\mathrm{g}$ in a Beckman J2-21 ultracentrifuge (Palo Alto, CA) using a JA-18.1 fixed angle rotor, and washed twice in buffer (0.1 M neutral ammonium acetate). The sediment was deposited on carbon-coated copper grids, stained with $2 \%$ potassium phosphotungstate $(\mathrm{pH} 7.0)$ and $2 \%$ uranyl acetate ( $\mathrm{pH} 4.0$ ), and then examined in a Philips EM 300 electron microscope operated at $60 \mathrm{kV}$. Magnification was monitored using T4 phage tails (113 nm in length) [78]. Particles were measured on prints at a final magnification of 297,000 times.

\section{Propagation of phages and their purification}

The phages were propagated at a multiplicity of infection (MOI) of 10 on E. coli O157:H7 strain R508 in $2.0 \mathrm{~L}$ of TSB containing $10 \mathrm{mM} \mathrm{MgSO}_{4}$ for $18 \mathrm{~h}$ at $37^{\circ} \mathrm{C}$ 


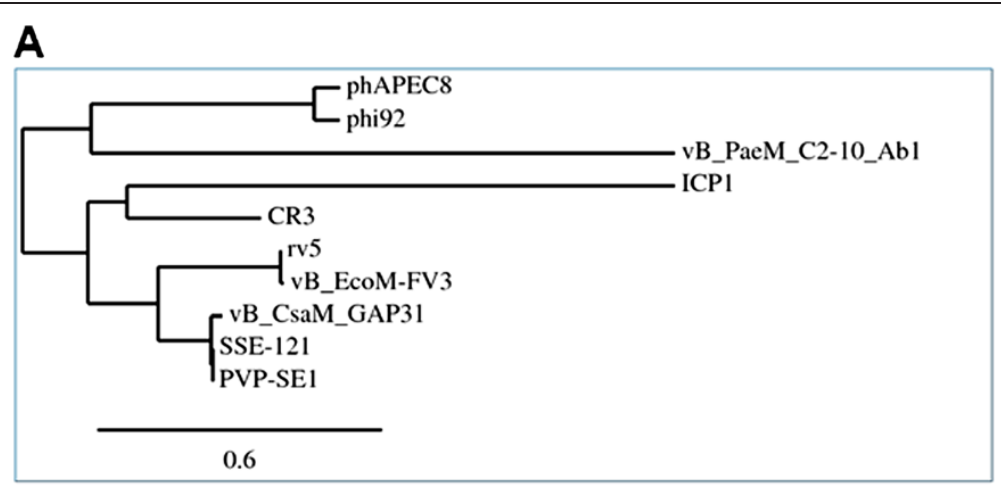

B

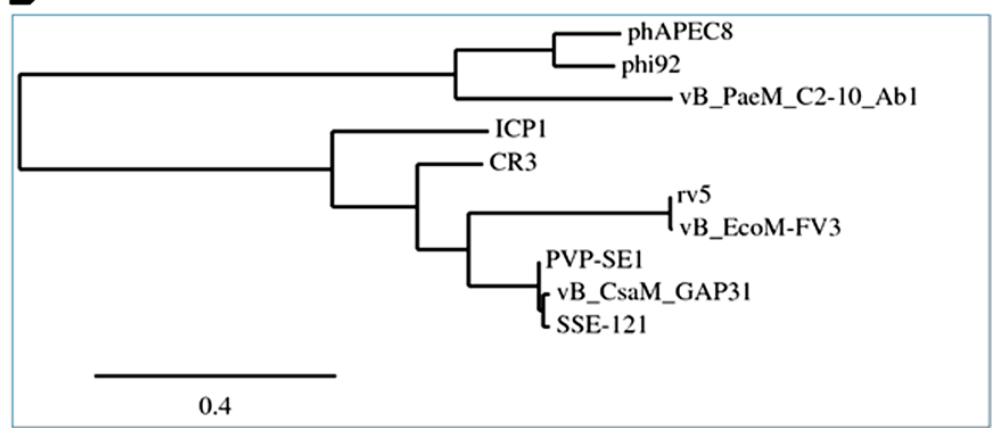

Figure 4 Phylogenetic analysis of rV5-related phage capsids protein (A) and DNA polymerases (B) using "one click at phylogeny.fr. Homologous proteins from Cronobacter phage C3 (NC_017974), Vibrio phage ICP1 (NC_015157) and Pseudomonas phage vB_PaeM_C2-10_Ab1 (HE983845) were used as outliers.

with shaking at $120 \mathrm{rpm}$. The resulting lysates were clarified by centrifugation at $6,000 \times g$ and pancreatic DNase 1 and RNase A (Sigma Aldrich, St. Louis, MO) were added to the filtrate to concentrations of $10 \mu \mathrm{g} / \mathrm{ml}$. The phages were precipitated with polyethylene glycol 8000 [79], and subsequently purified by cesium chloride step and equilibrium density gradient ultracentrifugation as described by Sambrook and Russell [80]. The final band was dialyzed at $4^{\circ} \mathrm{C}$ against two changes of $2 \mathrm{~L}$ of dialysis buffer $\left(10 \mathrm{mM}\right.$ Tris $\mathrm{HCl}, 10 \mathrm{mM} \mathrm{MgSO} 4.7 \mathrm{H}_{2} 0$, $25 \mathrm{mM} \mathrm{NaCl}, \mathrm{pH} 7.5,0.01 \%$ gelatin). The concentration of purified phages in the dialyzed suspension was determined by direct plaque assay with E. coli O157:H7 strain EC990298 as the host.

\section{Pulsed field gel electrophoresis (PFGE)}

The genome size of rV5 was characterized by PFGE [81] and data were analyzed using the BioNumerics program (Applied Maths, Austin, TX).

\section{Purification of phage DNA}

DNA for construction of a clone library was extracted from phage rV5 prepared as above to the stage of precipitation with PEG 8000 and sedimentation by ultracentrifugation. The pellet was resuspended in a minimal volume of lambda diluent. EDTA was then added to a concentration of $20 \mathrm{mM}$, and the phage DNA was extracted by sequential treatment with proteinase $\mathrm{K}$ (50 mg/ml), SDS $(0.5 \%, \mathrm{w} / \mathrm{v})$, phenol-chloroform extraction and ethanol precipitation [80]. The precipitated DNA was dissolved in water, tested for purity by electrophoresis in $0.9 \%$ agarose and by PCR for contaminating bacterial DNA using the malM gene of E. coli O157:H7 as a target. The concentration of DNA in the final preparation was calculated from its absorbance at $260 \mathrm{~nm}$.

\section{Genome sequencing}

The sequence of rV5 was derived initially from a clone library and subsequently by primer walking at The Centre for Applied Genomics (Toronto, ON, Canada). Primers were designed using Premier Biosoft's NetPrimer (http://www.premierbiosoft.com/netprimer/), and purchased from Sigma Genosys Canada (Oakville, ON). The sequences were assembled using the SeqMan program (DNASTAR, Madison, WI).

\section{Genome annotation}

Open reading frames (ORFs) were identified using Kodon (Applied Maths). The protein products of each ORF were examined for homologs using the programs PSI-BLASTP $[82,83]$ or Batch-BLAST (http://greengene. uml.edu/programs/NCBI_Blast.html. In certain cases the 
proteins were also subjected to HHpred [54,84] analysis at http://toolkit.tuebingen.mpg.de/hhrep. In addition, each protein was scanned for conserved protein motifs using Batch Web CD-Search Tool [85,86], TMHMM [41] and Phobius [41]. Transfer RNAs were detected using tRNAscan [37] and ARAGORN [38]. Codon usage information on E.coli O157:H7 strains was determined using data from the Forsyth Institute's Microbial Genome Codon Usage Database (http://exon.gatech.edu/ metagenome/CodonUsageDatabase/). The codon usage of rV5 was analyzed using DNAMAN software (Lynnon Corp., Vaudreuil-Dorion, QC, Canada). Potential terminators were located by ARNold [87] and verified using the MFOLD algorithm [88]. Putative promoters were identified in the sequence upstream $\left(5^{\prime}\right)$ of the genes by homology to the consensus sigma-70 promoters of E. coli (TTGACA (N15-20) TATAAT) using the "search sequences" feature of DNAMAN. As a further aid to identifying interesting regulatory sequences $100 \mathrm{bp}$ of $5^{\prime}$ upstream sequence data was extracted using extractUpStreamDNA at http://lfz.corefacility.ca/extractUpStreamDNA/ extractUpStreamDNA/ and submitted to MEME [89] at http://meme. sdsc.edu/.

For comparative genomic analyses we employed EMBOSS Stretcher at http://emboss.bioinformatics.nl/cgi-bin/ emboss/stretcher, while CoreGenes 2.0 [90,91] was used to compare proteomes. Phylogenetic analyses were carried out using "one click" at http://www.phylogeny.fr/ [92].

\section{Genome accession numbers}

The annotated genomic sequence of phage rV5 is available from the NCBI under the accession number DQ832317.

\section{Proteomics (sample preparation and MudPIT analysis)}

After unsuccessful attempts to disrupt phage rV5 by osmotic shock with sodium chloride, it was treated with $\mathrm{LiCl}$ (2). Six ml of $10 \mathrm{M} \mathrm{LiCl}$ were added to $6 \mathrm{ml}$ of purified dialysed phage rV5 containing $1.2 \times 10^{12} \mathrm{PFU}$. The mixture was incubated for $20 \mathrm{~min}$ at $46^{\circ} \mathrm{C}$ and then diluted 10-fold with dialysis buffer $(10 \mathrm{mM}$ Tris- $\mathrm{HCl}$, $10 \mathrm{mM} \mathrm{MgSO}_{4}, 25 \mathrm{mM} \mathrm{NaCl}, \mathrm{pH} \mathrm{7.5)}$ at $4^{\circ} \mathrm{C}$. After concentration to the starting volume $(6 \mathrm{ml})$ by centrifugation in a 10,000 molecular weight cut-off (MWCO) device (Amicon Centriprep YM10, Millipore Corporation, Bedford MA, USA), the concentrate was dialyzed against $4 \mathrm{~L}$ of dialysis buffer for $24 \mathrm{~h}$ in a 10,000 MWCO cassette (Pierce, Rockford, IL, USA). After dialysis, the sample was processed three times on an immobilized DNase 1 F7 ${ }_{M}$ matrix column (MoBiTec, Göttingen, Germany) with elution by gravity. The eluate was dialyzed as before, against two $4 \mathrm{~L}$ volumes of the same dialysis buffer to remove the cleaved DNA fragments and then concentrated to $0.5 \mathrm{ml}$ by centrifugation in a 10,000
MWCO device (Centriprep YM10) and stored at $-20^{\circ} \mathrm{C}$. The protein concentration was estimated from its absorbance at $280 \mathrm{~nm}$ at $1.59 \mathrm{mg} / \mathrm{ml}$.

Protein samples were suspended in $8 \mathrm{M}$ urea and $100 \mathrm{mM}$ Tris $\mathrm{pH} 8.5$, reduced with $100 \mathrm{mM}$ TCEP for $30 \mathrm{~min}$ followed by cysteine alkylation with $55 \mathrm{mM}$ iodoacetamide for another $30 \mathrm{~min}$ in the dark. The mixture was then diluted to $4 \mathrm{M}$ urea by adding 100 mM Tris buffer pH 8.5 (and $\mathrm{CaCl}_{2}$ was added to ensure tryptic specificity at $2 \mathrm{mM}$ ). Trypsin was then used to digest the protein samples at $37^{\circ} \mathrm{C}$ for $24 \mathrm{hrs}(1: 100$ enzyme:sample). The digestion was stopped with the addition of formic acid to $4 \%(\mathrm{v} / \mathrm{v})$ prior to column loading.

The protein digest was pressure-loaded onto a column containing $4 \mathrm{~cm}$ of $5 \mu \mathrm{m} \mathrm{C18}$ resin packed into $250 \mu \mathrm{m}$ inner diameter fused silica capillary with a M-520 $0.5 \mu \mathrm{m}$ filter assembly (IDEX Health \& Science LLC, Oak Harbor, WA), followed by desalting with $0.1 \%$ formic acid in 5\% acetonitrile. The loaded C18 column was then connected to $100 \mu \mathrm{m}$ (i.d.) analytical column consisting of $4 \mathrm{~cm}$ of packed $5 \mu \mathrm{m}$ strong cation exchange resin (SCX Partisphere, Whatman GE Healthcare) and $10 \mathrm{~cm}$ of packed C18 resin (Polymicro Technologies, Phoenix, AZ) with a $5 \mu \mathrm{m}$ laser pulled tip. The column assembly was placed inline and LC/LC-MS/MS was carried out as described earlier [93], using a 12-step separation with an Agilent HP1100 system connected to a LCQ Deca ion trap mass spectrometer (Thermo Scientific).

Tandem mass spectra were collected in a datadependent pattern by collecting one full MS scan $(\mathrm{m} / \mathrm{z}$ range $=400-1400$ ) followed by MS/MS spectra of the three most abundant precursor ions. The MS/MS spectra were then processed and searched against the protein database (NCBI) using the SEQUEST algorithm (http:// fields.scripps.edu/sequest/). All subsequent filtering and comparisons of identifications were made using DTASelect and Contrast software [94].

\section{Additional files}

Additional file 1: Table S1. Sensitivity of reference strains of 12 common phage types of E. coli O157:H7 to lysis by phage rV5.

Additional file 2: Table S2. Sensitivity of ECOR strains to lysis by phage rV5. Additional file 3: Table S3. rV5 genes, their products, homologs and potential function.

Additional file 4: Table S4. Predicted promoters and rho-independent terminators found in the rV5 genome.

Additional file 5: Table S5. MS data on rV5.

\section{Abbreviations}

AA: Amino acid; BLAST: Basic local alignment search tool; CFU: Colony forming unit, a measure of the number of viable bacterial cells;

DNase: Deoxyribonuclease; ECOR: Escherichia coli collection of reference; gp: Gene product; LC-MS: Liquid chromatography-mass spectrometry; MAFFT: Multiple alignment using fast fourier transform; MOI: Multiplicity of 
Infection, ratio of infective phage particles to vulnerable hosts; MSMS: Tandem mass spectrometry; MudPIT: Multi-dimensional protein identification technology; PDB: Research collaboratory for structural bioinformatics (rcsb) protein data bank; PFU: Plaque forming unit, a measure of the number of viable viral particles; RNase: Ribonuclease; TCEP: (tris(2carboxyethyl)phosphine); TMHMM: TransMembrane prediction using Hidden Markov Models; TSB: Tryptic soy broth.

\section{Competing interests}

The authors have no competing interests to disclose.

\section{Authors' contributions}

AMK and RPJ designed and guided the project; TW, RPJ, and AM isolated rV5 and with $\mathrm{KF}, \mathrm{AM}$ and $\mathrm{EJ}$ were involved in the initial characterization of this phage; DMM and HWA performed the electron microscopy; EJL and AM arranged for the sequencing; EJL carried out the PFGE; JM and JY conducted the proteomic analyses; and AMK did the annotation. AMK did most of the writing of the paper and all authors read and approved the final manuscript.

\section{Acknowledgements}

AMK acknowledges research funding from the Natural Sciences and Engineering Research Council of Canada, and with other authors, funding from the Laboratory for Foodborne Zoonoses, Public Health Agency of Canada. These funding bodies did not have any role in the design of the experiments, in the collection, analysis, and interpretation of data; in the writing of the manuscript; or in the decision to submit the manuscript for publication.

The authors thank Dr. David Shub for his help in defining the location of the intron in rV5. The authors thank Dr. Jennifer Alami for her careful proofreading and corrections of this manuscript.

\section{Author details}

${ }^{1}$ Public Health Agency of Canada, Laboratory for Foodborne Diseases, 110 Stone Road West, Guelph, ON N1G 3W4, Canada. ${ }^{2}$ Department of Molecular and Cellular Biology, University of Guelph, Guelph, ON N1G 2W1, Canada. ${ }^{3}$ Abbott Point of Care, 185 Corkstown Road, Ottawa, ON K2H 8V4, Canada. ${ }^{4}$ Merck Research Laboratories, 126E Lincoln Avenue, Rahway, NJ 07065, USA. ${ }^{5}$ Département de Microbiologie-infectiologie et immunologie, Faculté de médecine, Université Laval, Québec, QC G1K 7P4, Canada. "Enteric Diseases Program, National Microbiology Laboratory, Public Health Agency of Canada, 1015 Arlington Street, Winnipeg, MB R3E 3R2, Canada. ${ }^{7}$ The Scripps Research Institute, Department of Cell Biology, Proteomic Mass Spectrometry Laboratory, 10550 North Torrey Pines Road, La Jolla, CA 92037, USA.

Received: 12 June 2012 Accepted: 28 February 2013

Published: 6 March 2013

\section{Reference}

1. Bolton DJ: Verocytotoxigenic (Shiga toxin-producing) Escherichia coli: virulence factors and pathogenicity in the farm to fork paradigm. Foodborne Pathog Dis 2011, 8:357-365.

2. Karmali MA: Host and pathogen determinants of verocytotoxinproducing Escherichia coli-associated hemolytic uremic syndrome. Kidney Int Suppl 2009, 112:S4-S7.

3. Stanford K, McAllister TA, Niu YD, Stephens TP, Mazzocco A, Waddell TE, Johnson RP: Oral delivery systems for encapsulated bacteriophages targeted at Escherichia coli 0157:H7 in feedlot cattle. J Food Prot 2010, 73:1304-1312

4. Niu YD, Stanford K, Kropinski AM, Ackermann HW, Johnson RP, She YM, Ahmed R, Villegas A, McAllister TA: Genomic, proteomic and physiological characterization of a T5-like bacteriophage for control of Shiga toxinproducing Escherichia coli 0157:H7. PLoS One 2012, 7:e34585.

5. Kutter EM, Skutt-Kakaria K, Blasdel B, el-Shibiny A, Castano A, Bryan D, Kropinski AM, Villegas A, Ackermann HW, Toribio AL, Pickard D, Anany H, Callaway T, Brabban AD: Characterization of a Vil-like phage specific to Escherichia coli 0157:H7. Virol J 2011, 8:430.

6. Ahmed R, Bopp C, Borczyk A, Kasatiya S: Phage-typing scheme for Escherichia coli 0157:H7. J Infect Dis 1987, 155:806-809.

7. Viazis S, Akhtar M, Feirtag J, Brabban AD, Diez-Gonzalez F: Isolation and characterization of lytic bacteriophages against enterohaemorrhagic Escherichia coli. J Appl Microbiol 2011, 110:1323-1331.
8. Ronner AB, Cliver DO: Isolation and characterization of a coliphage specific form Escherichia coli 0157:H7. J Food Prot 1990, 53:944-947.

9. Liao WC, Ng W, Lin IH, Syu WJ, Liu TT, Chang CH: T4-Like genome organization of the Escherichia coli O157:H7 lytic phage AR1. J Virol 2011, 85:6567-6578.

10. López-Cuevas O, Castro-Del CN, Léon-Felix J, González-Robles A, Chaidez C: Characterization of bacteriophages with a lytic effect on various Salmonella serotypes and Escherichia coli O157:H7. Can J Microbiol 2011, 57:1042-1051.

11. Dini C, De Urraza PJ: Isolation and selection of coliphages as potential biocontrol agents of enterohemorrhagic and Shiga toxin-producing E. coli (EHEC and STEC) in cattle. J Appl Microbiol 2010, 109:873-887.

12. Raya RR, Varey P, Oot RA, Dyen MR, Callaway TR, Edrington TS, Kutter EM, Brabban AD: Isolation and characterization of a new T-even bacteriophage, CEV1, and determination of its potential to reduce Escherichia coli 0157:H7 levels in sheep. Appl Environ Microbiol 2006, 72:6405-6410.

13. Raya RR, Oot RA, Moore-Maley B, Wieland S, Callaway TR, Kutter EM, Brabban AD: Naturally resident and exogenously applied T4-like and T5-like bacteriophages can reduce Escherichia coli 0157:H7 levels in sheep guts. Bacteriophage 2011, 1:15-24.

14. Kannan P, Yong HY, Reiman L, Cleaver C, Patel P, Bhagwat AA: Bacteriophage-based rapid and sensitive detection of Escherichia coli O157:H7 isolates from ground beef. Foodborne Pathog Dis 2010, 7:1551-1558.

15. McAllister TA, Stanford K, Bach SJ: Monitoring and migration of E. coli 0157:H7 in commercial dairies. Advances in Dairy Technology 2005, 17:227-246.

16. O'Flynn G, Ross RP, Fitzgerald GF, Coffey A: Evaluation of a cocktail of three bacteriophages for biocontrol of Escherichia coli 0157:H7. Appl Environ Microbiol 2004, 70:3417-3424.

17. Abuladze T, Li M, Menetrez MY, Dean T, Senecal A, Sulakvelidze A: Bacteriophages reduce experimental contamination of hard surfaces, tomato, spinach, broccoli, and ground beef by Escherichia coli 0157:H7. Appl Environ Microbiol 2008, 74:6230-6238.

18. Kudva IT, Jelacic S, Tarr PI, Youderian P, Hovde CJ: Biocontrol of Escherichia coli 0157 with 0157-specific bacteriophages. Appl Environ Microbiol 1999, 65:3767-3773.

19. Goodridge L, Chen J, Griffiths M: Development and characterization of a fluoresecent-bacteriophage assay for detection of Escherichia coli 0157: H7. Appl Environ Microbiol 1999, 65:1397-1404.

20. Perry LL, SanMiguel P, Minocha U, Terekhov Al, Shroyer ML, Farris LA, Bright N, Reuhs BL, Applegate BM: Sequence analysis of Escherichia coli 0157:H7 bacteriophage $\varphi \mathrm{V} 10$ and identification of a phage-encoded immunity protein that modifies the 0157 antigen. FEMS Microbiol Lett 2009, 292:182-186.

21. Hendrix RW, Casjens SR: Myoviridae, Siphoviridae, Podoviridae. In Virus Taxonomy. VIllth Report of the International Committee on Taxonomy of Viruses. Edited by Fauquet CM, Mayo MA, Maniloff J, Desselberger U, Ball LA. New York: Elsevier Academic Press; 2005:43-47.

22. Morita M, Tanji Y, Mizoguchi K, Akitsu T, Kijima N, Unno H: Characterization of a virulent bacteriophage specific for Escherichia coli 0157:H7 and analysis of its cellular receptor and two tail fiber genes. FEMS Microbiol Lett 2002, 211:77-83.

23. Park M, Lee JH, Shin H, Kim M, Choi J, Kang DH, Heu S, Ryu S: Characterization and comparative genomic analysis of a novel bacteriophage, SFP10, simultaneously inhibiting both Salmonella enterica and Escherichia coli 0157:H7. Appl Environ Microbiol 2012, 78:58-69.

24. Sheng H, Knecht HJ, Kudva IT, Hovde CJ: Application of bacteriophages to control intestinal Escherichia coli 0157:H7 levels in ruminants. Appl Environ Microbiol 2006, 72:5359-5366.

25. Tanji Y, Shimada T, Yoichi M, Miyanaga K, Hori K, Unno H: Towards a rational control of Escherichia coli $0157: \mathrm{H} 7$ by a phage cocktail. Appl Microbiol Biotechnol 2004, 64:270-274.

26. Kropinski AM, Lingohr EJ, Moyles DM, Ojha S, Mazzocco A, She YM, Bach SJ, Rozema EA, Stanford K, McAllister TA, Johnson RP: Endemic bacteriophages: a cautionary tale for evaluation of bacteriophage therapy and other interventions for infection control in animals. J Virol 2012, 9:207.

27. Villegas A, She YM, Kropinski AM, Lingohr EJ, Mazzocco A, Ojha S, Waddell TE, Ackermann HW, Moyles DM, Ahmed R, Johnson RP: The genome and 
proteome of a virulent Escherichia coli 0157:H7 bacteriophage closely resembling Salmonella phage Felix O1. Virol J 2009, 6:41.

28. Lavigne R, Darius P, Summer EJ, Seto D, Mahadevan P, Nilsson AS, Ackermann H-W, Kropinski AM: Classification of Myoviridae bacteriophages using protein sequence similarity. BMC Microbiol 2009, 9:224.

29. Adriaenssens EM, Ackermann HW, Anany H, Blasdel B, Connerton IF, Goulding D, Griffiths MW, Hooton SP, Kutter EM, Kropinski AM, Lee JH, Maes M, Pickard D, Ryu S, Sepehrizadeh Z, Shahrbabak SS, Toribio AL, Lavigne R: A suggested new bacteriophage genus: "Viunalikevirus". Arch Virol 2012, 157:2035-2046.

30. Kropinski AM, Lingohr EJ, Moyles DM, Chibeu A, Mazzocco A, Franklin K, Villegas A, Ahmed R, She YM, Johnson RP: Escherichia coli O157:H7 typing phage V7 is a T4-like virus. J Virol 2012, 86:10246-12.

31. Kropinski AM, Kovalyova IV, Billington SJ, Butts BD, Patrick AN, Guichard JA Hutson SM, Sydlaske AD, Day KR, Falk DR, McConnell MR: The genome of $\varepsilon 15$, a serotype-converting, Group E1 Salmonella enterica-specific bacteriophage. Virology 2007, 369:234-244.

32. Waddell TE, Mazzocco A, Pacan J, Johnson R, Ahmed R, Poppe C, Khakhria C: Use of bacteriophages to control Escherichia coli 0157 infections in cattle. United States Patent No 2002, 6:485,902.

33. Waddell T, Mazzocco A, Johnson R, Pacan J, Campbell S, Perets A, MacKinnon J, Holtslander B, Poppe C, Gyles C: Control of Escherichia coli 0157:H7 infection of calves by bacteriophages. 1st edition. Kyoto, Japan: Fourth International International Symposium and Workshop on Shiga toxin (verocytotoxin)-producing Escherichia coli (VTEC 2000); 2000:1-2.

34. Ochman H, Selander RK: Standard reference strains of Escherichia coli from natural populations. J Bacteriol 1984, 157:690-693.

35. Lior H: Classification of Escherichia coli. In Escherichia coli in Domestic Animals and Humans. Edited by Gyles CL. Wallingford, UK: CAB International; 1994:31-72.

36. Kropinski AM: Sequence of the genome of the temperate, serotypeconverting, Pseudomonas aeruginosa bacteriophage D3. J Bacteriol 2000, 182:6066-6074.

37. Lowe TM, Eddy SR: tRNAscan-SE: a program for improved detection of transfer RNA genes in genomic sequence. Nucleic Acids Res 1997, 25:955-964.

38. Laslett D, Canback B: ARAGORN, a program to detect tRNA genes and tmRNA genes in nucleotide sequences. Nucleic Acids Res 2004, 32:11-16.

39. Santos SB, Kropinski AM, Ceyssens PJ, Ackermann HW, Villegas A, Lavigne R, Krylov VN, Carvalho CM, Ferreira EC, Azeredo J: Genomic and proteomic characterization of the broad-host-range Salmonella phage PVP-SE1: creation of a new phage genus. J Virol 2011, 85:11265-11273.

40. Sonnhammer ELL, von Heijne G, Krogh A: A hidden Markov model for predicting transmembrane helices in protein sequences. In Proceedings of the Sixth International Conference on Intelligent Systems for Molecular Biology. Edited by Glasgow J, Littlejohn T, Major F, Lathrop R, Sankoff D, Sensen C. Menlo Park, CA: AAAl Press; 1998:175-182.

41. Kall L, Krogh A, Sonnhammer EL: A combined transmembrane topology and signal peptide prediction method. J Mol Biol 2004, 338:1027-1036

42. Miller EC, Kutter E, Mosig G, Arisaka F, Kunisawa T, Rüger W: Bacteriophage T4 genome. Microbiol Mol Biol Rev 2003, 67:86-156.

43. Bailey $T L$, Elkan $C:$ The value of prior knowledge in discovering motifs with MEME. ISMB 1995, 3:21-29.

44. Kassavetis GA, Butler ET, Roulland D, Chamberlin MJ: Bacteriophage SP6specific RNA polymerase. II. Mapping of SP6 DNA and selective in vitro transcription. J Biol Chem 1982, 257:5779-5788.

45. Geiduschek EP, Kassavetis GA: Transcription of the T4 late genes. Virol $J$ 2010, 7:288

46. Lundin D, Torrents E, Poole AM, Sjoberg BM: RNRdb, a curated database of the universal enzyme family ribonucleotide reductase, reveals a high level of misannotation in sequences deposited to Genbank. BMC Genomics 2009, 10:589.

47. Kropinski AM, Lingohr EJ, Ackermann HW: The genome sequence of enterobacterial phage 7-11, which possesses an unusually elongated head. Arch Virol 2011, 156:149-151.

48. Morello E, Saussereau E, Maura D, Huerre M, Touqui L, Debarbieux L: Pulmonary bacteriophage therapy on Pseudomonas aeruginosa cystic fibrosis strains: first steps towards treatment and prevention. PLoS One 2011, 6:e16963.

49. Shin H, Lee JH, Kim Y, Ryu S: Complete genome sequence of Cronobacter sakazakii bacteriophage CR3. J Virol 2012, 86:6367-6368.
50. Grigoriev A: Analyzing genomes with cumulative skew diagrams. Nucleic Acids Res 1998, 26:2286-2290.

51. Lobry JR, Lobry C: Evolution of DNA base composition under no-strand-bias conditions when the substitution rates are not constant. Mol Biol Evol 1999, 16:719-723.

52. Lobry JR: Genomic landscapes. Microbiology Today 1999, 26:164-165.

53. Grigoriev A: Strand-specific compositional asymmetries in doublestranded DNA viruses. Virus Res 1999, 60:1-19.

54. Hildebrand A, Remmert M, Biegert A, Soding J: Fast and accurate automatic structure prediction with HHpred. Proteins 2009, 77(Suppl 9):128-132.

55. Kostyuchenko VA, Leiman PG, Chipman PR, Kanamaru S, van Raaij MJ, Arisaka F, Mesyanzhinov W, Rossmann MG: Three-dimensional structure of bacteriophage T4 baseplate. Nat Struct Biol 2003, 10:688-693.

56. Pearson WR, Wood T, Zhang Z, Miller W: Comparison of DNA sequences with protein sequences. Genomics 1997, 46:24-36.

57. Lupas A: Predicting coiled-coil regions in proteins. Curr Opin Struct Bio 1997, 7:388-393.

58. Lupas A, Van DM, Stock J: Predicting coiled coils from protein sequences. Science 1991, 252:1162-1164.

59. Schwarzer D, Buettner FF, Browning C, Nazarov S, Rabsch W, Bethe A, Oberbeck A, Bowman VD, Stummeyer K, Muhlenhoff M, Leiman PG, Gerardy-Schahn R: A multivalent adsorption apparatus explains the broad host range of phage phi92: a comprehensive genomic and structural analysis. J Virol 2012, 86:10384-10398.

60. Mikkonen M, Alatossava T: A group I intron in the terminase gene of Lactobacillus delbrueckii subsp. lactis phage LL-H. Microbiology 1995, 141:2183-2190.

61. Young R: Bacteriophage lysis: mechanism and regulation. Microbiol Rev 1992, 56:430-481.

62. Grundling A, Bläsi U, Young R: Biochemical and genetic evidence for three transmembrane domains in the class I holin, lambda S. J Biol Chem 2000, 275:769-776.

63. Young $\mathrm{R}$, Bläsi U: Holins: form and function in bacteriophage lysis. FEMS Microbiol Rev 1995, 17:191-205.

64. Pickard D, Thomson NR, Baker S, Wain J, Pardo M, Goulding D, Hamlin N, Choudhary J, Threfall J, Dougan G: Molecular characterization of the Salmonella enterica serovar Typhi Vi-typing bacteriophage E1. J Bacteriol 2008, 190:2580-2587.

65. The National Microbiology Laboratory (NML) andCentre for Food-borne Environmental and Zoonotic Infectious Diseases (CFEZID) PHAoC, Provincial Public Health Microbiology Laboratories: 2009 Annual Summary of Laboratory Surveillance Data, Including Serotype and Phage Types Tables for 2007-2009, NESP and NML. 2009. http://www.nml-Inm.gc.ca/NESP-PNSME/ surveillance-2009-eng.html.

66. Viscardi M, Perugini AG, Auriemma C, Capuano F, Morabito S, Kim KP, Loessner MJ, lovane G: Isolation and characterisation of two novel coliphages with high potential to control antibiotic-resistant pathogenic Escherichia coli (EHEC and EPEC). Int J Antimicrob Agents 2008, 31:152-157.

67. Fischer D, Eisenberg D: Finding families for genomic ORFans. Bioinformatics 1999, 15:759-762.

68. Yin Y, Fischer D: Identification and investigation of ORFans in the viral world. BMC Genomics 2008, 9:24.

69. Truncaite L, Simoliunas E, Zajanckauskaite A, Kaliniene L, Mankeviciute R, Staniulis J, Klausa V, Meskys R: Bacteriophage vB_EcoM_FV3: a new member of "rV5-like viruses". Arch Virol 2012, 157:2431-2435.

70. Tsonos J, Adriaenssens EM, Klumpp J, Hernalsteens JP, Lavigne R, De GH: Complete genome sequence of the novel Escherichia coli phage phAPEC8. J Virol 2012, 86:13117-13118.

71. Abbasifar R, Kropinski AM, Sabour PM, Ackermann HW, Alanis VA, Abbasifar A, Griffiths MW: Genome sequence of Cronobacter sakazakii myovirus vB CsaM GAP31. J Virol 2012, 86:13830-13831.

72. Ceyssens PJ, Brabban A, Rogge L, Lewis MS, Pickard D, Goulding D, Dougan G, Noben JP, Kropinski A, Kutter E, Lavigne R: Molecular and physiological analysis of three Pseudomonas aeruginosa phages belonging to the "N4like viruses". Virology 2010, 405:26-30

73. Ceyssens PJ, Miroshnikov K, Mattheus W, Krylov V, Robben J, Noben JP, Vanderschraeghe S, Sykilinda N, Kropinski AM, Volckaert G, Mesyanzhinov V, Lavigne R: Comparative analysis of the widespread and conserved PB1like viruses infecting Pseudomonas aeruginosa. Environ Microbiol 2009, 11:2874-2883. 
74. Ceyssens PJ, Glonti T, Kropinski NM, Lavigne R, Chanishvili N, Kulakov L, Lashkhi N, Tediashvili M, Merabishvili M: Phenotypic and genotypic variations within a single bacteriophage species. Virol J 2011, 8:134.

75. Lavigne R, Seto D, Mahadevan P, Ackermann H-W, Kropinski AM: Unifying classical and molecular taxonomic classification: analysis of the Podoviridae using BLASTP-based tools. Res Microbiol 2008, 159:406-414.

76. Pedulla ML, Ford ME, Houtz JM, Karthikeyan T, Wadsworth C, Lewis JA, Jacobs-Sera D, Falbo J, Gross J, Pannunzio NR, Brucker W, Kumar V, Kandasamy J, Keenan L, Bardarov S, Kriakov J, Lawrence JG, Jacobs WR Jr, Hendrix RW, Hatfull GF: Origins of highly mosaic mycobacteriophage genomes. Cell 2003, 113:171-182

77. Darling AE, Mau B, Perna NT: progressiveMauve: multiple genome alignment with gene gain, loss and rearrangement. PLoS One 2010, 5:e11147.

78. Voelker R, Sulakvelidze A, Ackermann HW: Spontaneous tail length variation in a Salmonella myovirus. Virus Res 2005, 114:164-166.

79. Yamamoto KR, Alberts BM, Benzinger R, Lawhorne L, Treiber G: Rapid bacteriophage sedimentation in the presence of polyethylene glycol and its application to large-scale virus purification. Virology 1970, 40:734-744.

80. Sambrook J, Russell DW: Molecular Cloning: A Laboratory Manual. 3rd edition. Cold Spring Harbor, New York: Cold Spring Harbor Press; 2001.

81. Lingohr E, Frost S, Johnson RP: Determination of bacteriophage genome size by pulsed-field gel electrophoresis. Methods Mol Biol 2009, 502:19-25.

82. Altschul SF, Gish W, Miller W, Myers EW, Lipman DJ: Basic local alignment search tool. J Mol Biol 1990, 215:403-410.

83. Altschul SF, Madden TL, Schaffer AA, Zhang J, Zhang Z, Miller W, Lipman DJ: Gapped BLAST and PSI-BLAST: a new generation of protein database search programs. Nucleic Acids Res 1997, 25:3389-4022

84. Soding J, Biegert A, Lupas AN: The HHpred interactive server for protein homology detection and structure prediction. Nucleic Acids Res 2005 33:W244-W248

85. Marchler-Bauer A, Lu S, Anderson JB, Chitsaz F, Derbyshire MK, DeWeeseScott C, Fong JH, Geer LY, Geer RC, Gonzales NR, Gwadz M, Hurwitz DI, Jackson JD, Ke Z, Lanczycki CJ, Lu F, Marchler GH, Mullokandov M, Omelchenko MV, Robertson CL, Song JS, Thanki N, Yamashita RA, Zhang D, Zhang N, Zheng C, Bryant SH: CDD: a conserved domain database for the functional annotation of proteins. Nucleic Acids Res 2011, 39:D225-D229.

86. Derbyshire MK, Lanczycki CJ, Bryant SH, Marchler-Bauer A: Annotation of functional sites with the Conserved Domain Database. Database 2012 2012:bar058

87. Macke TJ, Ecker DJ, Gutell RR, Gautheret D, Case DA, Sampath R: RNAMotif, an RNA secondary structure definition and search algorithm. Nucleic Acids Res 2001, 29:4724-4735.

88. Zuker M, Zuker M: Mfold web server for nucleic acid folding and hybridization prediction. Nucleic Acids Res 2003, 31:3406-3415.

89. Bailey TL, Elkan C: Fitting a mixture model by expectation maximization to discover motifs in biopolymers. Menlo Park, CA USA: AAAI Press; 1994:28-36.

90. Zafar N, Mazumder R, Seto D: CoreGenes: a computational tool for identifying and cataloging "core" genes in a set of small genomes. BMC Bioinforma 2002, 3:12.

91. Kropinski AM, Borodovsky M, Carver TJ, Cerdeno-Tarraga AM, Darling A, Lomsadze A, Mahadevan P, Stothard P, Seto D, Van DG, Wishart DS: In silico identification of genes in bacteriophage DNA. Methods Mol Biol 2009, 502:57-89.

92. Dereeper A, Guignon V, Blanc G, Audic S, Buffet S, Chevenet F, Dufayard JF, Guindon S, Lefort V, Lescot M, Claverie JM, Gascuel O: Phylogeny.fr: robust phylogenetic analysis for the non-specialist. Nucleic Acids Res 2008, 36:W465-W469.

93. Washburn MP, Wolters D, Yates JR III, Washburn MP, Wolters D, Yates JR: Large-scale analysis of the yeast proteome by multidimensional protein identification technology. Nat Biotechnol 2001, 19:242-247.

94. Tabb DL, McDonald WH, Yates JR III, Tabb DL, McDonald WH, Yates JR: DTASelect and Contrast: tools for assembling and comparing protein identifications from shotgun proteomics. J Proteome Res 2002, 1:21-26.

\section{doi:10.1186/1743-422X-10-76}

Cite this article as: Kropinski et al:: The host-range, genomics and proteomics of Escherichia coli O157:H7 bacteriophage rV5. Virology Journal 2013 10:76.

\section{Submit your next manuscript to BioMed Central and take full advantage of:}

- Convenient online submission

- Thorough peer review

- No space constraints or color figure charges

- Immediate publication on acceptance

- Inclusion in PubMed, CAS, Scopus and Google Scholar

- Research which is freely available for redistribution 